\title{
ANDEN VERDENSKRIG FORTALT FOR BØRN OG UNGE HISTORIEFORTOLKNINGER I NYERE DANSK BØRNELITTERATUR
}

\begin{abstract}
SECOND WORLD WAR NARRATED FOR CHILDREN AND YOUNGSTERS. INTERPRETATION OF HISTORY IN NEW DANISH LITERATURE FOR CHILDREN | Chil-
\end{abstract} dren's books about the Second World War have been written and published ever since it ended. One would perhaps imagine that the ever-increasing distance from it would mean a waning interest, but that does not seem to be the case. Over the last few years, a whole range of remarkable children's books have appeared in Denmark. New things can still be written about this period, and the time gap can be said to have had the effect of freeing up material. This should not be taken as meaning that newer books are less reliable, historically speaking, but rather that they present the period in a new light. In this article a number of recent Danish novels will be discussed with respect to how they deal with history. It is not the intention to try to make non-fiction out of historical novels for children, which would mean reading the books in a manner which was at variance with the genre they belong to, but one of the premises of the article is that the historical novel is to be understood as a form of discourse lying somewhere between history and pure fiction. The historical novel is seen as a piece of fiction presenting one or several interpretations of a given period of history by setting its story in a particular context.

KEYWORDS I children's literature, second world war, memory, historical interpretation, historical novel

Den historiske roman er en velanskrevet genre inden for dansk børnelitteratur, og Anden Verdenskrig er uden sammenligning den hyppigst beskrevne periode inden for genren. Siden krigens afslutning er der udgivet mere end I6o titler om emnet, og der er ingen tegn på, at populariteten er aftagende. Tværtimod er der inden for de seneste ti år udkommet flere nye titler om året, og der udvikles hele tiden nye vinkler på stoffet, samtidig med at kendte motiver gennemspilles på nye måder. Der er udført flere registranter, som dokumenterer de mange titler og sågar peger på en stigende tendens i 200o'erne (Mortensen; Gude). Det kunne se ud til, at den tidsmæssige afstand til Anden Verdenskrig har betydet en vis frisættelse af motiver og synsvinkler, som tidligere blev opfattet som grænseoverskridende eller ligefrem var tabuiseret i fortællinger for børn. Eksempelvis har tyske flygt- 
ningebørn, søskende til Østfrontfrivillige, børn af danske nazister og unge tyske soldater fået en stemme i nyere danske børnebøger, hvilket står i modsætning til de lidt ældre børnelitterære værkers snævrere fokusering på medlemmer og børn af modstandsbevægelsen i Danmark, på redningen af danske jøder og ikke mindst på hverdagen for såkaldt almindelige danske børn. Tidligere var de danske børnebøger alene besættelsestidsbørnebøger, dvs. med et særskilt nationalt fokus, men inden for de seneste to årtier har internationale forhold og samspillet mellem nationale og internationale problemstillinger fået langt større plads. Denne artikels mål er at sætte fokus på den udvikling, der er sket inden for genren den historiske roman i dansk børnelitteratur inden for de seneste IO-I5 år. Formidlingen af Anden Verdenskrig vil fungere som et eksempel på, hvordan en periode af stor betydning for den nationale selvforståelse hele tiden genskrives, fortolkes og iscenesættes på nye måder for barnelæseren. I et bredere perspektiv stilles spørgsmålet om, hvorfor og hvordan mødet mellem historieformidling og fiktion forvaltes i netop den historiske roman for børn.

Inden for det børnelitterære kredsløb er det ikke bare forfatterne, men også formidlerne, dvs. anmeldere, bibliotekarer, lærere og skolebibliotekarer, som finder de fiktive værker om Anden Verdenskrig vigtige. Historiske romaner om Anden Verdenskrig får relativt meget omtale i aviser og børnelitterære tidsskrifter i forhold til anden børnelitteratur, og ved uddelingen af forskellige priser er det ofte blevet understreget, at bøger i denne genre udgør et bidrag til børns historiske indsigt og dannelse. Såvel udenlandske som danske titler er gennem tiden blevet belønnet med priser og andre hædersbevisninger. Det gælder både for den prestigiøse internationale H.C. Andersen-medalje og for Kulturministeriets Børnebogspris, at de flere gange er givet til bøger, som tematiserer Anden Verdenskrig for et børnepublikum. H.C. Andersen-medaljen er eksempelvis tilfaldet Uri Orlev for Øen i Fuglegaden (I98I, dansk udgave i988), som handler om en drengs kamp for overlevelse i den jødiske ghetto i Warszawa, og Kulturministeriets Børnebogspris blev i 1982 givet til Knud Erik Pedersen for Esben, der handler om et mindre barns oplevelse af 9. april og besættelsen af Nordjylland; i I999 tilfaldt samme pris Martin Petersen for Med ilden i ryggen, som drejer sig om tyske flygtningebørns skæbne i Danmark; og i 2005 gik prisen til Birgit Strandbygaard for Drengen der samlede på ord, som beskriver krigens langvarige konsekvenser for en gruppe børn med familierelationer til henholdsvis modstandsfolk og Østfrontfrivillige.

Skolen er en helt central institution for udbredelsen af de historiske romaner, hvilket hænger sammen med en mere end Ioo år gammel tradition for fortællende historieundervisning. I starten af I90o-tallet stod denne tradition meget stærkt, og der blev skrevet en lang række børneromaner, som understøttede (eller kompenserede for) lærernes evne til at fortælle Danmarkshistorie. I takt med at skole- og videnskabsfaget historie i mellemkrigsårene blev videnskabeliggjort, blev idealet en mere nøgtern og fagbogsformidlet historieundervisning, men efter den såkaldte sproglige vending inden for historievidenskaben, hvor interessen henledtes på den litterære og fortællende del af historieformidlingen, blev grundskolefaget historie 
i den sidste del af I9oo-tallet igen optaget af netop at fortelle historie (se Poulsen, Historie; Poulsen, "Fortællingen”). Dermed var der igen plads til de historiske romaner i historieundervisningen, og samtidig styrkedes også genrens position i det tværfaglige samarbejde mellem fagene historie og dansk.

Således har en del af de danske børnelitterære titler om Anden Verdenskrig haft betydning som generationslæsning, idet de har været anvendt i grundskolens historie- og danskundervisning. Værker som Klaus Rifbjergs Kesses krig (I98I) og Bjarne Reuters Drengene fra Skt. Petri (I99I) har været blandt de hyppigst fælleslæste værker i grundskolen i flere årtier, og disse titler er i de senere år blevet suppleret med Martin Petersens Med ilden i ryggen (1999), Benni Bødkers Besattelse (2005) og Birgit Strandbygaards Drengen der samlede på ord (2005). Senest er Morten Dürrs Det skjulte kort (20I2) blevet indkøbt i klassesæt til en del centre for undervisningsmidler, hvilket peger på en fremtid som klasserumslæsning for også dette værk. De fire sidstnævnte værker danner udgangspunkt for denne artikels refleksion over udviklingen i og betydningen af den historiske roman i nyere dansk børnelitteratur. Værkerne er valgt, fordi de er eksponenter for en udvikling og på den måde kan siges at udgøre genrens fortrop. Samtidig må netop disse værker antages allerede at have fået og i de kommende år yderligere at få indflydelse på dannelsen af en kollektiv bevidsthed om Anden Verdenskrig, fordi de er anerkendte af de børnelitterære formidlere (gennem prisuddelinger, anmeldelser og indkøb), og fordi de i høj grad læses i klasserumssammenhænge og dermed fortolkes af mange børn (og mange lærere).

Der skelnes i denne artikel ikke mellem børne- og ungdomslitteratur, selvom både Med ilden i ryggen, Bescttelse og Det skjulte kort i større eller mindre udstrækning indeholder typiske ungdomslitterære motiver såsom forelskelse, spirende seksualitet, opgør med forældre og andre autoriteter osv. Fokus i denne artikel ligger dog særligt på formidlingen af det historiske stof, og derfor anvendes kategorien børnelitteratur som en samlende kategori for både børne- og ungdomslitteratur. Børnelitteratur er i denne optik tekster skrevet af voksne til børn, som i henhold til FNs børnekonvention er mennesker under I8 år.

\section{Den historiske roman som børnelittercer genre}

Den historiske roman for børn deler nogle grundlæggende træk med den historiske roman i litteraturen i almindelighed, men derudover er der en række forhold, som er særlige for den historiske roman for børn. Generelt for den historiske roman gælder ifølge litteraten Ole Birklund Andersen, at den deltager i en dobbeltdiskurs ved dels at være en fiktionstekst og dels at hævde sig som en tekst med et indhold, som kan efterprøves uden for litteraturen. Grundlæggende fremstår genren altså paradoksal, og det stiller både litteraturen og læseren i en vanskelig rolle: På den ene side indbyder værkerne i genren til en historisk referentiel læsning, og på den anden side fungerer værkerne på normale skønlitterære præmisser, hvortil hører, at de ikke kan forpligtes på en virkelighed uden for litteraturen. 
Fordelen ved historiske fiktioner er imidlertid, at dobbeltdiskursen er erklæret og åbenlys. Med romanformen bliver det tydeligt, at fortiden er konstrueret, og at historiske begivenheder, personer og situationer bliver fortolket i en ny form. Ole Birklund Andersen beskriver meget præcist historiske romaner som en genskrivning og videredigtning oven på et hierarki af allerede eksisterende historiske og fiktive fortællinger (Andersen 9). På trods af den historiske romans åbenlyse dobbeltdiskurs forekommer genrens paradoksalitet dog ikke altid indlysende i forbindelse med anvendelse og diskussion af børnelitteraturens historiske romaner. Fordi historiske romaner ofte optræder i skolen, kan der være en tendens til at forstå teksternes indhold som en autoritativ historiefortolkning. Især når teksterne anvendes til historieundervisning, bliver de betragtet som kildeskrifter, mens de i forbindelse med danskundervisning ofte analyseres helt uden skelen til den historiske kontekst. Det viser i hvert fald analyser af nyere undervisningsmidler til de to fag (Skyggebjerg I2-I5). Den ideelle didaktiske praksis er naturligvis, at undervisningen $\mathrm{i}$ og med historiske romaner tager hensyn til genrens dobbelthed og både tager højde for fiktionen og den historiske referentialitet. Læsning af historiske romaner vil i så fald kunne give en historisk metabevidsthed, her forstået som en bevidsthed om historieskrivning som fortalt og konstrueret.

I forhold til den videre genredefinition kan man sige, at en historisk roman ud fra en bred forståelse må være en fiktionstekst, som foregår i fortiden og udsiger noget om denne. Problemet kan imidlertid være at definere, hvad fortiden er. Nogle teoretikere har stillet krav om, at handlingen skal foregå forud for forfatterens levetid, hvis der skal være tale om en historisk roman (Toijer-Nilsson; Svensen). En sådan definition ville dog få den absurde konsekvens, at Kesses krig ikke ville kunne kategoriseres som historisk roman, da Rifbjerg er født i I93I, mens Drengene fra Skt. Petri akkurat ville kunne antages, idet Reuter er født i I950. Det siger sig selv, at et sådant skel ikke er tilfredsstillende. En anden mulighed er at definere fortiden som noget overstået eller afsluttet, som man kaster et retrospektivt blik på. Dette kan give en form for mening i de tilfælde, hvor der skrives om en krigseller konfliktperiode, og det er muligt at fastsætte en egentlig afslutning; men i tilfælde, hvor der ikke findes en præcis begivenhed eller en fastsat periode med en klar afslutning, er en sådan definition heller ikke meningsfuld. Samtidig vil et sådant krav være i konflikt med et historiesyn, som er processuelt og vægter gradvise forandringer og fortidens indflydelse på nutiden. Historikeren Sven Sødring Jensen formulerer det således:

"Defineres historie ved hjælp af tidsbegreber, fører det ofte til antikvariske betragtninger. Hvor lavt et nummer skal et år have for at kunne opnå prædikatet "historie"? Jeg vil betragte historie som en proces, der begyndte engang, udspiller sig i dag og fortsætter ind i fremtiden. Historie som samfundets og menneskeslægtens forandringsproces rykker antikviteterne ned fra hylden og ind i en sammenhæng, der udelukker, at årstal sætter grænser for, hvad der er historie.” (Jensen 7I) 
Sven Sødring Jensen erstatter altså det, han opfatter som et mekanisk krav til en bestemt tidsmæssig afstand til det fortalte, med et indholdsmæssigt krav om vægtning af historiske forandringsprocesser. Spørgsmålet er så, hvad disse forandringsprocesser måtte være kendetegnet ved, og hvor meget eller hvor lidt de ville kunne fylde i handlingen. Sødring Jensen er vag på dette punkt og repræsenterer hermed en inkluderende opfattelse af både historiebegrebet $\mathrm{i}$ almindelighed og den historiske roman i særdeleshed. Hans vægtning af begreberne samfund og menneskeslægt indikerer, at forholdet mellem individ og kollektiv spiller en særlig rolle, og at den historiske roman i sin fremstilling af personer, tid og rum netop rummer en mulighed for at stille skarpt på den lille historie i den store. Den konflikt eller forandringsproces, som er samfundets, bliver også et individuelt anliggende.

I forståelsen af den historiske roman som en måde at formidle en beskrevet periodes tidstypiske mønstre, som dækker både samfund og individ og tillige både fysisk rum og mentalitet lægger Sødring Jensen sig i forlængelse af den generelle genreteori om den historiske roman, som den er udviklet af den marxistiske litteraturteoretiker Georg Lukács. Han har bl.a. stillet krav om, at en historisk roman må være befolket med personer, som optræder i overensstemmelse med den tid, de repræsenterer (Lukács I5). Alternativt vil der ikke være tale om historiske romaner, men i stedet om kulisseromaner, som er præget af nutidsmennesker iklædt fortidens gevandter. Lukács vægter ikke mindst gengivelsen af hverdagen, og de mentale mønstre er ligeså vigtige som fysiske tidsmarkører i form af genstande, episoder og symboler. Endelig bliver det for Lukács og senere genreteori vigtigt, at den historiske roman kan fremstille ordinære menneskers liv med samme legitimitet som berømte personer.

Disse krav bliver gennem Sødring Jensen og børnelitteraturforskeren John Stephens også stillet til den historiske roman for børn, men ikke mindst Stephens problematiserer samtidig kravet om karakterer og mentale mønstre i overensstemmelse med den fremstillede periode. Ud fra analyser af en række børnelitterære værker kommer Stephens til den konklusion, at de fremstillede konflikter og perioder (den fortalte tid) i børnelitteraturens historiske romaner altid er projektionsflade for forfatterens samtidsforståelse(r). Sagt med andre ord er de børnelitterære værker $i$ en eller anden forstand altid kulisseromaner (fordi de handler ligeså meget om nutiden som om fortiden), og samtidig er de præget af en didaktisk intention om at lære børn om fortiden, så dens fortrædeligheder ikke vil gentage sig. Stephens finder det ydermere karakteristisk, at børnelitteraturens historiske romaner har en tendens til at transformere historiske særegenheder til universelle sandheder, der egentlig er formet af den ideologi og den specifikke kulturelle kontekst, som forfatteren er en del af:

"The historical novel in children's literature is the discoursal product of firm ideological intentions, written and read in a specific complex cultural situation. It has always performed a moral, and even didactic function, especially through 
its capacity to transform events which appear to be historical particularities into universals of human experiences.” (Stephens 238)

Med John Stephens' erkendelser in mente virker den historiske roman for børn som en genre, der fordrer analytisk opmærksomhed, og ureflekteret anvendelse af historiske romaner i historieformidlingens tjeneste forekommer ganske problematisk, idet skiftende tiders historiesyn og ideologier ifølge Stephens har overordentlig stor indflydelse på netop denne genre. Samtidig er det en væsentlig pointe hos både Stephens, Sødring Jensen og Povlsen, at historiske romaner tilbyder indlevelse i en verden, som ellers virker fremmed og uforståelig for det nutidige barn, og at denne indlevelse indeholder et erkendelsesmæssigt og didaktisk potentiale. De historiske romaner har stor gennemslagskraft over for barnelæseren ved at sætte fokus på andre børn i historiske situationer, og derudover kan anvendelsen af eksempelvis sanseappel gennem fremstilling af kulde, sult, smag og lugte understøtte læseoplevelsen og hukommelsen. Barnelæseren kan gennem en historisk roman få fornemmelsen af "at have været der selv", hvilket en fagbog sjældent giver, og historiske romaner kan skabe engagement og interesse for historie. Samtidig vil tekstanalyser af historiske romaners præmisser og litterære strategier i en undervisningssituation kunne være medvirkende i udviklingen af en generel kildekritisk kompetence, som også ville kunne anvendes ved læsning af andre typer af tekster.

\section{Fra heltepatos til hverdagsskildringer}

Som antydet indledningsvist har danske børnebøger gennemgået en markant udvikling i formidlingen af Anden Verdenskrig fra at være heltebeskrivelser og hverdagsbesættelsestidslitteratur til at være bredere og mere inkluderende $\mathrm{i}$ forståelsen af både perioden og dens konflikter. Denne udvikling kan tilskrives den generelle udvikling i den kollektive forståelse af Anden Verdenskrig, og den kan også tilskrives en almen udvikling i synet på barnet i børnelitteraturen. Ifølge Torben Weinreich er dansk børnelitteraturs behandling af Anden Verdenskrig frem til omkring I970 præget af "heltepatos" (Weinreich I39), dvs. der ses en stærk fokusering på frihedskampen, og børnebøgerne viser et fast og polariseret værdisystem med gode danske og onde tyske aktører. Der skelnes ikke i denne periode mellem tyskere og nazister, og tyskere er per definition repræsentanter for nationalsocialismen. Børnelitteraturen adskiller sig fra den almene litteratur ved at blive relativt længe i denne enkle og dikotomiske historiefortolkning, og dansk børnelitteratur er også længere tid om at opnå en kritisk distance, der tillader mere individuelle perspektiver og tabubehandling, end f.eks. tysk børnelitteratur.

Som en parentes kan det nævnes, at den tyske forfatter Hans Peter Richters Damals war es Friedrich (I96I, dansk titel Drengen Friedrich) indeholder en nuanceret fremstilling af jødeforfølgelsernes forudsætninger og konsekvenser for børn. Med en tysk drengs øjne ser man, hvordan optrapningen af den politiske retorik før krigen påvirker hverdagslivet og den mentale indstilling. Hovedpersonen mister 
langsomt forbindelsen med sin jødiske barndomsven Friedrich, som under krigen må leve alene under jorden, efter familien er blevet deporteret. Vennen findes til sidst død efter et bombardement, hvorfra han ikke kunne søge beskyttelse. Richters roman er interessant, fordi hovedpersonen hverken fremstilles som skyldig eller uskyldig. Hans baggrund og bevæggrunde bliver forklaret, men samtidig er han et individ, som måske kunne have handlet anderledes i enkelte situationer og have bidraget til en anden skæbne for Friedrich. Bogen fortælles med synsvinkel hos barnet, samtidig med at dette barn positioneres som medløber. Dermed antydes det, at også børn har et ansvar for kollektive stemninger og handlinger, hvilket er nyt i børnelitteraturen på dette tidspunkt.

Dansk børnelitteratur er i I970'erne og starten af I980'erne præget af historiske hverdagsfremstillinger, dvs. bøger som beskriver dagliglivet for såkaldt almindelige danske børn eller børn, som lever et relativt upåvirket liv, mens deres forældre, lærere eller andre f.eks. kan optræde i rollen som modstandsfolk. Hjørdis Varmers Det forår da far gik under jorden (I980) og Knud Erik Pedersens Esben (1982) er eksempler herpå. Begge bøger er dele af serier, som har yngre børn som hovedpersoner og også henvender sig til et relativt yngre publikum. Bøgerne fremstiller et barneliv, hvor krigen optræder et sted i periferien og udløser utryghed, men meget små konflikter for det fremstillede barn, og flyveblade, rationeret sukker og erstatningskaffe udgør en slags tidskolorit. Klaus Rifbjergs Kesses krig (I98I) tilhører også gruppen af hverdagsfortællinger, men den udgør samtidig et markant brud i denne sammenhæng, fordi romanen for første gang i dansk børnelitteratur fremstiller et menneskeligt billede af de kvinder, som forelskede sig i tyske soldater. Synsvinklen i romanen ligger hos en dreng, der har en ven, hvis mor er tyskerpige. Den i samfundets øjne amourøse mesalliance udgør også en knast i venskabet mellem de to drenge, men i romanens optik har såvel kærlighed som venskab en selvstændig legitimitet, selvom omgivelserne kan gøre relationerne vanskelige.

Udover hverdagsfortællingen er sabotageromanen et almindeligt genremønster i dansk børnelitteraturs fremstilling af Anden Verdenskrig. Ifølge Torben Weinreich er en sabotageroman kendetegnet ved at veksle mellem passager, hvor våben stjæles og sabotageaktioner finder sted, og mere refleksive passager, hvor der gives plads til diskussioner om mål og midler i kampen mod besættelsesmagten (Weinreich II8). Derudover er sabotageromanerne også ofte kærlighedsromaner, hvor flere i en modstandsgruppe bejler til den samme pige, og forelskelse ofte fører til fejlvurderinger i forhold til tillid og risici. Sabotageromanen er ikke noget særskilt børnelitterært fænomen, og sabotageromanerne i børnelitteraturen alluderer ofte til almenlitterære eksempler, f.eks. Tage Schou Hansens De nøgne trcer (I957). Den bedst kendte sabotageroman i børnelitteraturen er uden konkurrence Bjarne Reuters Drengene fra Skt. Petri (199I), som delvist bygger på Knud Pedersens selvbiografiske Churchillklubben (1946). Drengene fra Skt. Petri bekræfter det nævnte genremønster, hvor kærlighed og krig kombineres, men derudover spiller kammeratskabet mellem en gruppe drenge og deres overgang til voksenlivet en betydelig rolle. At romanen også er filmatiseret (Søren Kragh-Jacobsen I99I) har uden tvivl medvirket til dens 
udbredelse, og blandingen af det historiske stof og de ungdomslitterære træk er sammen med et velfungerende plot også sandsynlige forklaringer på værkets popularitet. Drengene fra Skt. Petri indeholder ikke en væsentlig ændring i forståelsen af Anden Verdenskrig i forhold til tidligere litteratur, men bekræfter derimod hidtidige dikotomier og opfattelser af, hvad modstandskampen indeholdt af opofrelse og heltemodighed i kampen for uantastelige idealer. Samtidig må romanen dog siges at indeholde en nuanceret refleksion over netop personlig og kollektiv motivation for modstandskamp, idealer, mål og ikke mindst tilladte midler. På den måde er romanen ikke fuldstændig éntydig i sin fremstilling af rigtigt og forkert, godt og ondt.

Den generelle udvikling i dansk børnelitteraturs fremstilling af Anden Verdenskrig er altså en langsom bevægelse væk fra fastlåste dikotomier og helteskildringer. Samtidig er de historiske romaner i dansk børnelitteratur helt indtil årtusindskiftet optaget af at skildre nationale forhold og besættelsestiden som et afrundet hele fra besættelsen den 9. april I940 til befrielsen den 5. maj 1945. Dansk børnelitteratur bekræfter hermed Claus Bryld og Anette Warrings identifikation af en grundlæggende nationalt forankret fortælling i både faglig og populær historieskrivning om perioden. Historieskrivningens hovedindhold er ifølge Bryld og Warring netop "besættelsen med modstandskampen og den dansk-tyske konflikt som det absolut mest dominerende" (Bryld og Warring 56).

\section{På vej vak fra det nationale fokus}

Når børnelitteraturen omkring årtusindskiftet forlader den nationale fokusering og begynder at fortælle andre historier end modstandskampens og de lokalt forankrede hverdagsberetninger med almindelige danske børn i hovedrollen, følges den sandsynligvis også med både faglig historieskrivning og populærhistoriske fremstillinger i eksempelvis aviser, dokumentar- og spillefilm samt anden litteratur. Det er dog ikke muligt her fuldt ud at dokumentere, og det forekommer, at børnelitteraturen indimellem er om ikke foran, så i hvert fald med i fortroppen, når historieskrivningen suppleres med nye fortællinger. Muligvis er det, fordi man i børnelitteraturen relativt upåagtet for den brede offentlighed kan bryde hidtidige tabuer. Derudover er børnelitteraturens force naturligvis barnets perspektiv, hvilket den brede historieskrivning ikke har været særskilt optaget af.

Martin Petersens Med ilden i ryggen (1999) er en manifestation af kursskiftet i dansk børnelitteraturs behandling af Anden Verdenskrig. Hovedpersonen i romanen er den I2-årige Klaus, som kommer fra en preussisk provinsby. Da den sovjetiske hær ved krigens slutning nærmer sig byen, må Klaus flygte sammen med sin mor og sine to søstre. Under flugten oplever de bombardementer, lovløshed og overgreb, og udmattede ankommer de til Østersøkysten, hvor de bliver væk fra hinanden i de store menneskemængders tumultariske kamp for at redde sig videre. Klaus og hans lillesøster kommer om bord i det herostratisk berømte skib Wilhelm Gustloff, og søsteren drukner, da skibet synker. Traumatiseret ankommer 
Klaus til en skole i København, hvor han efter en rum tid forenes med sin mor og storesøster. I København behandles de afmålt og fjendtligt, hvilket eskaleres, da de umiddelbart efter krigens slutning anbringes i en flygtningelejr i Vestjylland. De har forbud mod at omgås lokale, de fratages alle ejendele, og de ydmyges såvel fysisk som psykisk, selvom der også findes behjertede mennesker, bl.a. en præst som udbreder evangeliet for flygtningene såvel som for egne landsmænd. Der er kun nødtørftig lægehjælp til Klaus, som lider efter tabet af sin lillesøster, og da Klaus’ kønne storesøster bliver gravid med en dansk mand, hun illegalt har haft samkvem med, bliver denne fængslet, og Klaus’ familie får påbud om at rejse tilbage til Tyskland. Klaus er symbolsk nok født i 1933 og kan derfor ikke tillægges noget personligt ansvar for nazismen, men i Danmark bliver han tillagt en form for arvesynd, og han bliver som flygtningebarn dobbelt offer for krigen, altså både offer i sit hjemland og i modtagelseslandet Danmark.

Med ilden i ryggen har Klaus som førstepersonsfortæller, og derfor er forståelsen af krigen begrænset til det tyske barns synsvinkel. Klaus fremstår både naiv og bange, og han forstår eksempelvis ikke, at opsynsmændene i lejren blot er store drenge, der som tidligere frihedskæmpere har deres egne bevæggrunde og traumer at slås med. Historien fortælles dog retrospektivt, og den voksne (og erfarne) Klaus blander sig indimellem i barnet Klaus' beretning, og derved bliver læseren undertiden beriget med en indsigt, som er større end flygtningebarnets. Med ilden i ryggen modtog som sagt Kulturministeriets Børnebogspris og blev rost af den daværende kulturminister Margrethe Vestager for at formidle nyt og vigtigt historisk stof til børn og unge. Værd at bemærke er det, at Med ilden i ryggen udkom før Kirstens Lylloffs ph.d.-afhandling Barn eller fjende? Uledsagede tyske flygtningeborn $i$ Danmark I945 - 1949 (2005). Denne afhandling medførte i midten af 200o'erne en omfattende debat om de tyske flygtninges skæbne i Danmark.

I 2005 udkom både Benni Bødkers Besattelse og Birgit Strandbygaards Drengen der samlede på ord. De to romaner indeholder åbenlyse forskelle i formidlingen af Anden Verdenskrig, idet Besattelse er en sabotageroman, og Drengen der samlede på ord er en ret stillestående fortælling, som faktisk også foregår i fredstid, dvs. lige efter krigens afslutning. Samtidig har de to romaner det til fælles, at de ligesom Med ilden i ryggen diskuterer spørgsmålet om, hvorvidt og hvordan familiens eller fædrenes synder nedarves på børnene. I begge romaner er hovedpersonerne danske børn, som er dybt påvirkede af deres respektive familiemedlemmers kontroversielle valg, og børnene må i begge romaner bøde for familiernes udstødelse fra de sociale fællesskaber.

I Bescttelse beslutter hovedpersonen sig for at gå ind i den danske modstandsbevægelse, selvom han som barn af en dansk nazist egentlig var prædestineret til at slutte sig til den modsatte fløj. Hans beslutning motiveres af, at han mister sin storebror på Østfronten. Da han efter brorens død finder en række illusionsløse breve, som faren ellers har forholdt ham, erkender han, at storebroren er blevet forledt af den nazistiske ideologi. Romanen er formet som en tredjepersonsberetning, men brevene fra $\varnothing$ stfronten udgør en alternativ stemme, som ikke bare taler direkte til 
hovedpersonen og hans far om krigens meningsløshed og gru, men også til læseren. Med det dobbelte fortælleperspektiv gives plads til flere synsvinkler på krigen og de bagvedliggende ideologier og personlige motiver for at gå i kamp. Såvel faren som de to sønner fremhæver, at deres engagement er begrundet i national stolthed, men det betyder altså helt forskellige valg. Grundet sit ophav viser hovedpersonens vej ind i den danske modstandsbevægelse sig at være overordentlig vanskelig, og romanen slutter, idet han kaster sig ud i en selvplanlagt kamikazeaktion mod en fabrik. Slutningen er åben for fortolkning, og det læsende barn får ingen vished for aktionens succes og gives heller ingen indikationer på hovedpersonens fremtid.

I Drengen der samlede på ord er hovedpersonen ligeledes vokset op i en familie, hvor fattigdom og ledighed har tvunget både større børn og voksne til at træffe kontroversielle valg. Romanen foregår i I946-47, og selvom krigen officielt er slut, er konflikterne stadig aktuelle, og selvjustitsen lever. Hovedpersonens to brødre rejste under krigen til Østfronten for at kæmpe på tysk side, men kun den ene har overlevet. Denne bror oplever dog langtfra nogen behagelig hjemkomst, idet han kun når at vise sig for sin familie, før han bogstavelig talt bliver forstødt fra sin hjemegn. I det lille samfund, hvor romanen foregår, lever der også en pige, hvis storebror var en dansk modstandsmand, som blev dræbt i forbindelse med en sabotageaktion. Ligesom hovedpersonen er hun fuldstændig blevet glemt i de voksnes sorg og forsøgsvise måde at hævne fortiden på. Børnene ses således som ofre for voksnes konflikter og valg. Drengen der samlede på ord er dog relativt optimistisk i sin udgang, idet de optrædende børn udvikler deres egne måder at hele fortiden på. Hovedpersonen insisterer på at leve i sin helt egen verden, hvor mærkelige ord bliver hans livsindhold, og gennem sin autodidakte digtning udøver han en form for terapi over for sig selv og andre børn. Gennem sproget skabes en ny verden, der fungerer som en - $\mathrm{i}$ romanens optik - positiv form for eskapisme.

Morten Dürrs Det skjulte kort er det seneste eksempel på børnelitteratur, som skildrer overgangen mellem krigs- og fredstid. Denne roman viser ligesom de foregående, hvordan konflikterne ikke bare stopper, fordi befrielsen indtræffer. Romanen tager udgangspunkt i situationen for de tyske krigsfanger og soldater, som var udstationeret på Vestkysten. En del af handlingen foregår i sommeren 1945 under minerydningen, som fulgte efter krigsafslutningen og skulle overstås, inden tyskerne endeligt blev beordret hjem. Samtidig indeholder romanen et parallelt handlingsforløb i nutiden, hvor en dreng finder et hengemt minerydningskort og dermed åbner en mental port til fortiden. Drengen i nutiden afdækker ved hjælp af kortet og en telepatisk kontakt til et genfærd (i form af en dræbt soldat) en fortælling om, hvordan de tilbageholdte tyskere i sommeren ' 45 blev udsat for både hævn og selvtægt, og hvordan de både måtte undvære beskyttelsesudstyr og oversigtskort i minerydningen. Derfor mistede en del af dem livet, mens andre mistede førligheden i det arbejde, som ikke var en krigshandling, men skulle være en sikring af fred og sikkerhed.

Med det dobbelte handlingsplan og ikke mindst anvendelsen af et genfærd, som ikke kan finde hvile efter at være blevet offer i minerydningen, må Det skjulte kort 
siges at have nogle meget tydelige fiktionsmarkører, der advarer mod læsningen af romanen som et direkte billede af fortiden. Romanens fortalthed fremgår særdeles tydeligt, også for en barnelæser. Samtidig indeholder Det skjulte kort et for historiske børnebøger typisk efterskrift, som virker autenticitetsskabende, fordi der henvises til faghistoriske kilder, der dokumenterer de to millioner miner på Vestkysten og minerydningens 300 ofre. Mødet mellem fiktion og historieformidling er altså meget tydeligt, og romanen balancerer mellem underholdning og didaktik.

\section{Perspektiver i skildringen af Anden Verdenskrig}

Den historiske roman for børn er i overvejende grad en national orienteret genre. Det gælder ikke blot i dansk børnelitteratur, men i børnelitteratur generelt (Glasenapp). Der findes langt flere oversatte værker inden for fantasylitteraturen end inden for den historiske roman, og internationale bestsellere er meget sjældent historiske romaner for børn. Det synes at være en lovmæssighed, at historiske romaner rejser dårligt, fordi de oftest tager udgangspunkt i nationale forhold og problematikker. Trods denne tilsyneladende lovmæssighed har danske børnelæsere dog hele tiden haft adgang til et lille antal oversatte værker af bl.a. Hans-Peter Richter og Uri Orlev. Romaner af disse forfattere har i princippet kunnet nuancere danske børnelæseres forestilling om den konkrete historiske periode, men når det gælder kanonisering i skolen, har de danske børneromaner forrang. Derfor forekommer det også vigtigt, at disse romaner afspejler en nuanceret og adækvat forståelse af den skildrede periode.

Af de foregående eksempler kan man udlede, at et snævert besættelsestidsfokus i børnelitteraturen de senere år er blevet fulgt af en relativ åbning i forhold til at tematisere emner og konflikter, der viser Anden Verdenskrig som et internationalt fænomen. Samtidig er der flere romaner, som beskriver tiden lige efter Anden Verdenskrig og dermed hævder krigens konflikter som langvarige. Der er blevet plads til andre synsvinkler end dem, der dominerede i de tidligere fortællinger om hverdagsliv og modstandskamp, og der kan spores en forsigtig opblødning i traditionelle billeder af ven og fjende. Både modstandsfolk, Østfrontfrivillige, tyske soldater og flygtninge fremstår som nuancerede karakterer med individuelle baggrunde og motiver til at handle, som de gør. Børn af både vindere og tabere ses som ofre for krigen, og ligesom i anden samtidig børnelitteratur er kløften mellem barn og voksen en meget væsentlig dikotomi i de nyere historiske romaner. Uanset hvilket ophav man har, må man som barn selv håndtere fortiden og tage ansvar for fremtiden, synes de nyere børnebøger at sige. Hermed bekræfter eksemplerne det, som John Stephens har bemærket ud fra sit angelsaksiske materiale, nemlig at børnelitteraturens historiske romaner har en tendens til at skabe alment humanistiske pointer ud fra fremstillingen af historisk specifikke perioder.

Historiske romaner indskriver sig i en dobbeltdiskurs mellem historieformidling og ren fiktion, hvilket betyder, at man som fortolker må være opmærksom. Børnelitteraturens historiske romaner vil aldrig være autentiske kildeskrifter, og 
de vil aldrig kunne erstatte historiske fagbøger, heller ikke i skolen. Når det gælder motivation og engagement $\mathrm{i}$ historien, kan historiske romaner imidlertid være et væsentligt supplement til fagbøgerne, og de kan både fungere som grundlag for undervisning $\mathrm{i}$ en specifik historisk periode og som et grundlag for undervisning i historiografi, dvs. forskellige periodefortolkninger, herunder overvejelser over prioriteringer af bestemte begivenheder, konstruktioner af historiske personer og mentale skemaer. Ved sammenligninger af (lidt) ældre børnelitteratur om Anden Verdenskrig med nyere eksempler bliver man ikke mindst bevidst om, hvor hurtigt synet på en bestemt periode kan ændre sig.

\section{LITTERATURLISTE}

Andersen, Ole Birklund. Den faktiske sandheds poesi. Studier i bistorieromanen i forste balvdel af det 19 . arhundrede. Aarhus: Aarhus Universitetsforlag, 1996.

Bryld, Claus og Anette Warring. Besattelsestiden som kollektiv erindring. Frederiksberg: Roskilde

Universitetsforlag, 1998.

Bødker, Benni. Besattelse. København: Carlsen, 2005.

Dürr, Morten. Det skjulte kort. København: Carlsen, 2012.

Glasenapp, Gabriele von und Gisela Wilkending (Hrsg.). Geschichte und Geschichten. Frankfurt am Main: Peter Lang, 2005.

Gude, Anna Margrethe. "Fortiden fortalt". DANSK 3 (2012): 30-33.

Jensen, Sven Sødring. Historie og fiktion. Historiske børneromaner i undervisningen. København: Danmarks Lærerhøjskole, I990.

Lukács, Georg. The Historical Novel. Harmondsworth: Penguin, 1969.

Lylloff, Kirsten. Barn eller fjende? Uledsagede tyske flygtningeborn i Danmark 1945-1949. Ph.d.-afhandling, Københavns Universitet, 2005.

Mortensen, Hanne: "Besættelsestiden i danske børnebøger - Kan børnebøger bruges som kilder til beskrivelse af ændringer i historieopfattelsen over tid?” Nedslag i Børnelitteraturforskningen 7. Frederiksberg: Roskilde Universitetsforlag, 2006: I43-I62.

Orlev, Uri. Øen i Fuglegaden [198I]. København: Gyldendal, I988.

Pedersen, Knud Erik. Esben. København: Gyldendal, 1982.

Petersen, Martin. Med ilden i ryggen. København: Høst \& Søn, 1999.

Poulsen, Jens Aage. Historie, formidling og fiktion - den historiske roman i undervisningen. Brædstrup: Ålykke, 1990 .

Poulsen, Jens Aage. "Fortællingen - historieundervisningens problembarn eller columbusæg?" Henning Brinckmann og Lene Rasmussen, red.: Historieskabte såvel som historieskabende. 7 bistoriedidaktiske essays. Gesten: OP-forlag og Foreningen af lærere i Historie og Samfundsfag, 1996: 33-5I.

Reuter, Bjarne. Drengene fra Skt. Petri. København: Gyldendal, 199I.

Richter, Hans-Peter. Damals war es Friedrich [196I]. München: Dtv Junior, I979.

Rifbjerg, Klaus. Kesses krig. København: Gyldendal, 198I. 
Schou-Hansen, Tage: De nøgne træer [1957]. København: Gyldendal, 200I.

Skyggebjerg, Anna Karlskov. Den historiske roman for born. Teori, udvikling og analyse. Frederiksberg: Dansklærerforeningens forlag, 2008.

Stephens, John: Language and Ideology in Children's fiction. London \& New York: Longman, 1992. Strandbygaard, Birgit. Drengen der samlede på ord. København: Høst \& Søn, 2005.

Svensen, Åsfrid. "Undrende blikk på fortida: historiske romaner for barn og unge”. Forankring og fornying. Nordiske ungdomsromaner fram mot air 2000. Oslo: Cappelen/Dansklærerforeningen/ Gleerups Utbildningscentrum, 1999. 192-2IO.

Toijer-Nilsson, Ying. Minnet av i går. Stockholm: Raben \& Sjögren, I990.

Varmer, Hjørdis. Det forar da far gik under jorden [1980]. København: Forum, 2002.

White, Hayden. Metahistory. The Historical Imagination in Nineteenth-Century Europe [1973]. Baltimore: The John Hopkins University Press, 1993. 
